\title{
Screening of Selected Soil and Endophytic Fungi for Lovostatin Biosynthetic Genes lovE and lovF
}

\section{Bhargavi SD*, Praveen VK and Savitha J}

Department of Microbiology and Biotechnology, Bangalore University, Bangalore, India

\begin{abstract}
Lovastatin is a competitive inhibitor of the enzyme hydroxyl methylglutaryl coenzyme A reductase (HMGR) in cholesterol biosynthetic pathway and hence used in the treatment of hyperlipidemia. Our results revealed that Aspergillus terreus of soil origin produce copious amount of lovastatin than its counterpart that are endophytic in origin. Bioinformatics analysis of whole genome sequence of $A$. terreus (AH007774.1), a soil isolate revealed the presence of lovastatin gene cluster (AF141924.1 and AF141925.1), whereas, endophytic fungi including a species of $A$. terreus showed no homology with the lovastatin gene cluster. Molecular studies aimed at generating physical evidence were performed to analyze the expression of lovastatin biosynthetic genes lovE (regulatory gene) and lovF (transcriptional regulatory factor) in soil and endophytic fungi. The target PCR amplification of lovE (1512bp) and lovF (749bp) were successful in a strain of soil isolate, Aspergillus terreus (KM017693), whereas the same was not achieved in endophytic fungi. This is the first report on comparative analysis of complementary DNA sequence of a soil isolate and endophytic fungi, which further substantiate the absence of lovastatin production by endophytic fungi. The significance for the lack of lovastatin by endophytic fungi is also discussed.
\end{abstract}

Keywords: Lovastatin; LovE; LovF; A. terreus; Soil fungi; Endophytic fungi

\section{Introduction}

Lovastatin is a fungal secondary metabolite that competitively inhibits conversion of 3 hydroxy 3 methyl glutaryl coenzyme A (HMG $\mathrm{CoA}$ ) to mevalonate in cholesterol biosynthesis. Since its discovery and approval by Food and Drug Administration (FDA), it has been prescribed worldwide as a potential anticholesterolemic agent [1]. Several fungi belonging to the genera of Aspergillus, Penicillium, Monascus, Pleurotus are reported to be lovastatin producers [2], however, Aspergillus terreus is the only fungal isolate utilized for commercial production of lovastatin [1].

The lovastatin gene cluster consists genes for lovastatin nonaketide synthase $(\operatorname{lov} \mathrm{B})$, lovastatin diketide synthase $(\operatorname{lov} \mathrm{F})$, enoyl reductase $(\operatorname{lov} \mathrm{C})$, transesterase $(\operatorname{lov} \mathrm{D}), \mathrm{HMG}-\mathrm{CoA}$ reductase (ORF8), regulatory (lovE and ORF13) and cytochrome P450 monooxygenase. Lovastatin production is regulated by $l o v \mathrm{E}$ and deletion of the same results in cessation of lovastatin production whereas gene duplication increases yield by 5-7 fold [3,4]. Lov F encodes a diketide synthase and is needed for attachment of 2 methyl butyric acid chain to monacolin J to form monacolin L [5].

The transcription rates of $l o v \mathrm{E}$ and $l o v \mathrm{~F}$ have been studied in both submerged (SmF) and solid substrate fermentation (SSF) [6]. LovF transcripts were detected from the day 1 of its growth period where as $l o v \mathrm{E}$ was detected from day 3 onwards in SSF. In SmF transcription levels of both genes dropped as days progressed. LovE genes isolated from A. terreus (CCTCC AF93208) was cloned into the vector PMD$19 \mathrm{~T}(\mathrm{TaKaRa})$. Gene expression and sequencing studies confirmed the presence of $l o v \mathrm{E}$ gene in transformants [3].

In view of the preliminary findings that endophytic fungi lack DNA sequences that are homologous to lovastatin biosynthetic pathway genes [7], the present study was undertaken to obtain further insights into the lovastatin biosynthetic pathway genes in both soil and endophytic isolates using the two widely studied genes $l o v \mathrm{E}$ and $l o v \mathrm{~F}$.

\section{Materials and Methods}

\section{Isolation of endophytic fungi}

Endophytic fungi from different plants were isolated and characterized as described previously [8].

\section{Reinfection of plants with endophytic fungi}

Selected medicinal plant seeds (Piper nigrum, Garcinia cambogia, Coleus aromaticus, Venttivera zazonoides, Patchouli pogestomon) were purchased from Dhanvanthrivana, Jnanabharathi campus, Bangalore University, Bangalore, India. Seeds were washed thrice with sterile distilled water and sterilized with $2 \%$ sodium hypochlorite for 5 min. Washed seeds were ger minated on Murashige-Skoog medium [9] supplemented with $2 \%$ sucrose in temperature-controlled $\left(25^{\circ} \mathrm{C}\right)$ growth chambers under a $16 \mathrm{~h}$ light: $8 \mathrm{~h}$ darkness cycle for 2-3 weeks. Endophyte infection was performed by spraying spore suspension $\left(10^{6}\right.$ spores/ml) of selected endophytic fungi (Collectotrichum sp., Aspergillus terreus, Sordaria sp., Curvularia sp., Pithomyces sp., Pestalotiopsis sp., Phomopsis sp., Phoma sp., Podospora sp., Botrytis sp.,) onto the leaves of each plantlet. Plantlets were allowed to grow in the greenhouse for 2 months and leaves were tested for the presence of the inoculated endophytic fungi [10].

\section{Culturing of fungal strains}

To $100 \mathrm{ml}$ of Potato Dextrose Broth (PDB), $10 \mu \mathrm{l}$ of spore suspension

*Corresponding authors: Bhargavi SD, Department of Microbiology and Biotechnology, Bangalore University, Bangalore, India, Tel: 08022961461; E-mail: drsvtj@yahoo.co.in

Received September 21, 2015; Accepted October 01, 2015; Published October 08,2015

Citation: Bhargavi SD, Praveen VK, Savitha J (2015) Screening of Selected Soil and Endophytic Fungi for Lovostatin Biosynthetic Genes lovE and lovF. J Microb Biochem Technol 7: 334-337. doi:10.4172/1948-5948.1000235

Copyright: (C) 2015 Bhargavi SD, et al. This is an open-access article distributed under the terms of the Creative Commons Attribution License, which permits unrestricted use, distribution, and reproduction in any medium, provided the original author and source are credited. 
$\left(10^{7} / 10^{8}\right.$ spores $\left./ \mathrm{ml}\right)$ of test organisms was inoculated. The flasks were kept on orbital shaker at $120 \mathrm{rpm}$ at $30^{\circ} \mathrm{C}$ for 5 days followed by extraction of total RNA from fungal mycelia [8].

\section{Extraction of total RNA}

Total RNA from fungi was extracted following two different methods given below. Glassware used for total RNA isolation were treated with Di-Ethyl-Pyro-Carbonate (DEPC) water and dried overnight in the hot air oven.

\section{TRIZOL method}

One gram of filtered fungal biomass was ground to a fine powder under liquid $\mathrm{N}_{2}$ followed by the addition of $1 \mathrm{ml}$ of Trizol reagent (Sigma T9424), incubated for $15 \mathrm{~min}$ and $0.2 \mathrm{ml}$ of chloroform was added. Centrifugation was carried out at $12,000 \mathrm{rpm}$ for $15 \mathrm{~min}$ at $4^{\circ} \mathrm{C}$. Aqueous phase was transferred to a fresh tube and $0.5 \mathrm{ml}$ of 2-propanol was added. Sample was allowed to stand for 5-10 min at room temperature followed by centrifugation at $12,000 \mathrm{rpm}$ for $10 \mathrm{~min}$ at $4^{\circ} \mathrm{C}$. Supernatant was decanted and $1 \mathrm{ml}$ of absolute alcohol was added to the pellet. Centrifugation was carried out at 12,000 rpm for 15 $\min$ at $4^{\circ} \mathrm{C}$. Supernatant was discarded and the pellet was washed with $70 \%$ alcohol and re-suspended in DEPC water for subsequent use [11].

\section{STE (Sodium chloride, Tris and EDTA) method}

One gram of filtered fungal biomass was homogenized under liquid nitrogen in a pre-cooled mortar, transferred to a tube containing $500 \mu \mathrm{l}$ extraction buffer (0.1 M Tris- $\mathrm{HCl}$ (pH 8.0), 2 mM EDTA (pH 8.0),0.2 $\mathrm{M} \mathrm{NaCl}, 1 \% \mathrm{SDS}$ ) and mixed gently. Equal volume of PCI (Phenol/ Chloroform/Isoamyl alcohol (25:24:1, V/V/V)) was added immediately and mixed for $30 \mathrm{sec}$. The supernatant was pooled and PCI treatments were done twice to remove protein. Sodium acetate ( $1 / 10$ volume) (Ph 5.5) and 2.5 volume ethanol were added and mixed well, kept at $-20^{\circ} \mathrm{C}$ for $40 \mathrm{~min}$. After centrifugation the pellets were washed with $70 \%$ ethanol. Finally, the pellets were air dried and suspended in $100 \mu \mathrm{l}$ DEPC-treated water [12]. Resultant total RNA was visualized on $1 \%$ agarose gel and used for the construction of c-DNA.

\section{Construction of cDNA by reverse transcription}

Isolated total RNA was treated with DNase for $10 \mathrm{~min}$ at $37^{\circ} \mathrm{C}$ to remove residual DNA, if any, and the RNA was used for cDNA construction by following the instruction of First Strand cDNA synthesis kit for RT-PCR (AMV) from Roche, Germany (Kit No. 11483188001). The reaction was initiated by adding $2 \mu$ of $10 \mathrm{X}$ Reaction buffer, $4 \mu \mathrm{l}$ of $\mathrm{MgCl}_{2}(25 \mathrm{mM}), 2 \mu$ lof deoxynucleotide mix, $2 \mu \mathrm{l}$ of oligo- $\mathrm{P}(\mathrm{dT})_{15}$ primer, $1 \mu \mathrm{l}$ RNase inhibitor, $0.8 \mu \mathrm{l}$ of reverse transcriptase enzyme. To the above mixture $4 \mu \mathrm{l}$ of the isolated total RNA was added with variable volume of PCR grade water making up the volume to $20 \mu \mathrm{l}$, mixed well and briefly centrifuged to collect the reaction mixture at the bottom of the reaction tube. Reaction mixture was incubated at $25^{\circ} \mathrm{C}$ for $10 \mathrm{~min}$ and then $42^{\circ} \mathrm{C}$ for $60 \mathrm{~min}$ during which primer annealing and reverse transcription occurs respectively. Following $42^{\circ} \mathrm{C}$ incubation, the reverse transcriptase enzyme was denatured by incubating the reaction mixture at $99^{\circ} \mathrm{C}$ for $5 \mathrm{~min}$ and immediate cooling at $4^{\circ} \mathrm{C}$ for $5 \mathrm{~min}$ [13].

\section{Amplification of $l o v \mathrm{E}$ and $l o v \mathrm{~F}$ genes}

Primer sequence for $\operatorname{Lov} \mathrm{E}$ [3]

Forward: 5'-ATGGCTGCAGATCAAGGTATAT-3'

Reverse: 5'-TCATGGAGGAATATTGTTGAGG-3'

\section{LovF}

Forward: 5'-GCGTCGGTACATAAGGGGGG-3'; Reverse: 5'GTGGTTCCAAGGGTAGGGCGG-3'

Ribosomal 18S rRNA[6]

Forward: 5'-CGGCCCTTAAATAGCCCGGTCCG-3'

\section{Reverse: 5'-CGAGCCATTCAATCAATCGGTAGTAGCG-3'}

Primers for all targets were synthesized by Sigma (India) and Merck (India). The constructed cDNA was used as a template for PCR amplification using the designed primers. One Taq2X Master Mix with standard buffer (M0482S-NEB, England) was used for PCR amplification. This master mix was used at $1 \mathrm{X}$ concentration with DNA template and primers in a total reaction volume of $25 \mu$ l.Amplification conditions were set as follows: denaturation at $94^{\circ} \mathrm{C}$ for $5 \mathrm{~min}$; then 40 cycles, each consisting of denaturation $\left(94^{\circ} \mathrm{C}\right.$ for 30 seconds), annealing $\left(50^{\circ} \mathrm{C}\right.$ for 20 seconds) and extension $\left(72^{\circ} \mathrm{C}\right.$ for $1 \mathrm{~min}$ and 40 seconds); followed by a single extension at $72^{\circ} \mathrm{C}$ for $20 \mathrm{~min}$ [14]. Amplified product size of $l o v \mathrm{E}, \operatorname{lov} \mathrm{F}$, and $18 \mathrm{~S}$ ribosomal RNA was expected to be 1512 bp, $749 \mathrm{bp}$ and $300 \mathrm{bp}$ respectively. The amplified PCR products were run on $1 \%$ agarose gel and visualized for $l o v \mathrm{E}, \operatorname{lov} \mathrm{F}$ and Ribosomal 18SrRNA amplicons with the molecular weight marker.

\section{Results and Discussion}

Lovastatin is widely used as an anticholesterolemic drug worldwide. Researchers have screened several microbes for lovastatin production from various niches [5]. Also, comparative studies on lovastatin production by SmF and SSF have been reported at molecular level in soil fungi. Lovastatin production which is chiefly regulated by $l o v \mathrm{E}$ and $\operatorname{lov} \mathrm{F}$ has been widely studied and gene transfer studies indicate a pivotal role of lovE in cross platform gene transfer [6].

Although, endophytic fungi are now being exploited for various pharmaceutically valuable secondary metabolites, there are a very few reports of lovastatin which is also a secondary metabolite being produced by endophytes. We have previously demonstrated that endophytic fungi as poor producers of lovastatin since none of the 54 endophytic fungi isolated by us from medicinal plants produced any detectable level of lovastatin even after 10 days of incubation [9]. Also, it was noticed that Aspergillus terreus, an endophyte, did not produce lovastatin while a soil isolate of the same fungus produced significant levels of lovastatin under identical growth conditions [8]. Since not much information is available on lovastatin production by endophytic fungi, this study was designed to analyze and compare the genetic makeup of lovastatin producing Aspergillus terreus (KM017963), a soil isolate, with selected endophytic fungi of medicinal plants.

The bioinformatics study of whole genome sequences of endophytic fungi and a soil fungus (obtained from NCBI GenBank) for the presence of lovastatin gene cluster (AF141924.1andAF141925.1) was carried out. Whole genome sequence of $A$. terreus (AH007774.1), a soil isolate exhibited the presence of lovastatin gene cluster showing $100 \%$ homology, whereas, all other endophytic fungi including a species of Aspergillus terreus showed no homology with the lovastatin gene cluster [7]. $L o v \mathrm{E}$ and $l o v \mathrm{~F}$ are the part of this gene cluster.

$L o v \mathrm{E}$ and $\operatorname{lov} \mathrm{F}$ genes are involved in the lovastatin biosynthetic pathway. LovE gene encodes a transcription factor which regulates the expression of genes that participate in the biosynthetic pathway, whereas $\operatorname{lov} \mathrm{F}$ gene encodes a diketide synthase (DKS), one of the two polyketide synthases involved in lovastatin biosynthesis [6]. Thus both 
$\operatorname{lov} \mathrm{E}$ and $\operatorname{lov} \mathrm{F}$ are two important genes in the biosynthetic pathway of lovastatin. Therefore, studies at the transcriptional level were undertaken to ascertain the lack of lovastatin expression as measured by the lack of $l o v \mathrm{E}$ and $l o v \mathrm{~F}$ transcripts and the potential reason for the absence of $l o v \mathrm{E}$ and $l o v \mathrm{~F}$ gene expression in endophytes.

The study was initiated by isolating total RNA from the lovastatin producing fungus, $A$. terreus (KM017693) and 10 endophytic fungi namely Collectotrichum sp., A. terreus, Sordaria sp., Curvularia sp., Pithomyces sp., Pestalotiopsis sp., Phomopsis sp., Phoma sp., Podospora sp., Botrytis sp., isolated by us from medicinal plants. Reinfection of plants with isolated endophytic fungi confirmed its endophytic nature. Trizol reagent yielded total RNA in A. terreus (KM017693) and endophytic fungi except in Colletotrichum sp. Therefore, STE buffer was used to extract total RNA from the Colletotrichum sp. Agarose gel electrophoresis was subsequently used to check the integrity of the total RNA. Agarose gel separation of ribosomal RNA including $18 \mathrm{~S}$ rRNA and 28S rRNA subunits into distinct bands can be observed (Figure 1). Extraction of RNA was followed by construction of complementary DNA using reverse transcriptase enzyme. The resultant c-DNA was further used as a template for the amplification of desired genes $(\operatorname{lov} \mathrm{E}$ and $\operatorname{lov} \mathrm{F}$ ).

Reverse transcription followed by PCR amplification yielded PCR products (amplicon) for $\operatorname{lov} \mathrm{E}(1512 \mathrm{~kb}), \operatorname{lovF}(749 \mathrm{bp})$ and $18 \mathrm{~S}$ Ribosomal RNA (300bp) with Aspergillus terreus.

Ribosomal 18S rRNA (300bp) was used as a housekeeping gene

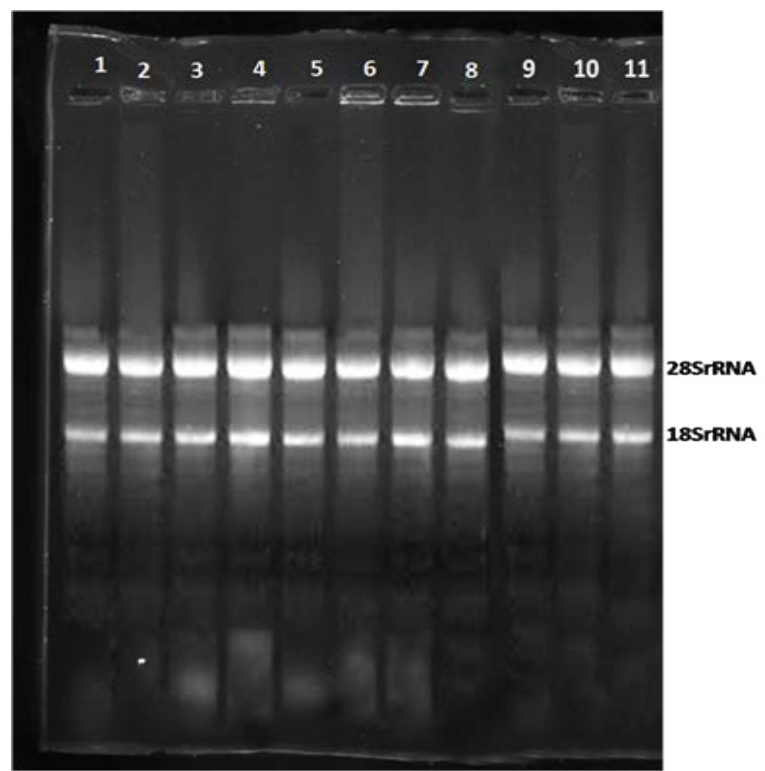

Figure 1: Total RNA of Aspergillus terreus and endophytic fungi on agarose gel.

Lane 1: A. terreus (KM017963),

Lanes 2 to 11: Total RNA isolated from endophytic fungi,

Lane 2: Collectotrichum. sp.

Lane 3: Aspergillus terreus,

Lane 4: Sordaria. sp.,

Lane 5: Curvularia. sp.,

Lane 6: Pithomyces. sp.,

Lane 7: Pestalotiopsis. sp.,

Lane 8: Phomopsis sp.,

Lane 9: Phoma. sp.,

Lane 10: Podopspora sp.

Lane 11: Botrytis. sp., respectively.

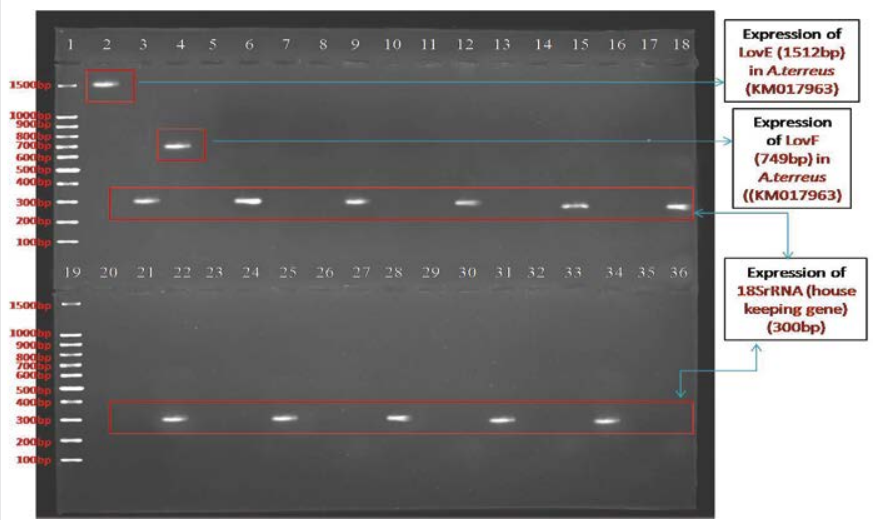

Figure 2: Electrophoresis of PCR products of Aspergillus terreus (L1) and endophytic fungi on agarose gel.

Lane 1 and 19: DNA marker (1500 bp to $100 \mathrm{bp}$ )

Lane 2, 3 and 4: LovE, 18SrRNA and LovF amplicons of Aspergillusterreus (soil fungus, KM017963)

Lanes $6,9,12,15,18,22,25,28,31$ and 34 : PCR amplicons of 18S rRNA in endophytic fungi

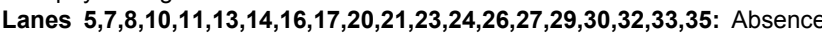

of LovE and LovF PCR amplicons in endophytic fungi.

(control gene) for all the fungi used. The gene coding for $18 \mathrm{~S}$ rRNA is a constitutive gene and expected to be present in all the samples. The presence of amplicon for 18S rRNA is indicative of the suitability of the assay conditions and test reagents used. Thus, it is also used as a validator of the results for the test organisms utilized in the study.

None of the ten endophytic fungi used in the study showed the presence of $\operatorname{lov} \mathrm{E}$ or $\operatorname{lov} \mathrm{F}$ amplicons but they showed the presence of $18 \mathrm{~S}$ rRNA amplicon at about $300 \mathrm{bp}$. These results clearly indicate that endophytic fungi do not express lovastatin biosynthetic pathway genes that are homologous to A. terreus lov $\mathrm{E}$ or lov $\mathrm{F}$ (Figure 2).

Results of our previous biochemical [8] bioinformatics [7] and our present molecular level approach have categorically enabled us to conclude that most, if not all of the endophytic fungi may not be the potential candidates for lovastatin production. The absence of lovastatin production by endophytic fungi may be attributed to the loss of genes responsible for lovastatin production during co-evolution along with host plant $[14,15]$. In plant system, HMGR plays a vital role in the mevalonate pathway for isoprenoid biosynthesis for normal plant development and adaptation to environmental stress [16]. If lovastatin inhibits HMG CoA reductase (HMGR), subsequent synthesis of plant growth promoting substances and pigments such as ABA, gibberellins, ubiquinone, isoprenoids, chlorophylls and carotenoids get inhibited as mevalonate is the precursor for the synthesis of above compounds. Further, inhibition of the growth of tobacco cells was observed at low concentrations of lovastatin and restoration of such inhibition by cytokinin has also been reported [17-20]. However, as observed by Crowell and Salaz, reduction of HMG COA to mevalonate is not the only rate limiting step in cytokinin biosynthesis.

It was also reported that lovastatin inhibits the biosynthesis of a-Farnesene, a major ester formed during scald development and fruits ripening in 'golden supreme' apples [21].

Thus, in light of the harmful effects of the fungal metabolite lovastatin on plants, it is tempting to speculate that the lack of lovastatin production in endophytic fungi is not to harm the plant host system in which they are residing in. This is been proved by unexpressed lovastatin 
Citation: Bhargavi SD, Praveen VK, Savitha J (2015) Screening of Selected Soil and Endophytic Fungi for Lovostatin Biosynthetic Genes lovE and lovF. J Microb Biochem Technol 7: 334-337. doi:10.4172/1948-5948.1000235

biosynthetic genes $\operatorname{lov} \mathrm{E}$ (regulatory gene) and $\operatorname{lov} \mathrm{F}$ (transcriptional regulatory factor) in endophytic fungi in our present study. However, this result will further be validated by sequencing the whole genome of Aspergillus terreus and comparing with that of endophytic fungi for lovastatin gene cluster.

\section{References}

1. Upendra RS, Pratima K, Amiri ZR, Shwetha L, Ausim M (2013) Screening and molecular characterization of natural fungal isolates producing lovastatin. Journal of Microbial and Biochemical Technology 5: 25-30.

2. Gulyamova TG, Ruzieva DM, Nasmetova SM, Sattarova RS, Lobanova KV, et al. (2013) Lovastatin production by Aspergillus terreus in solid state and submerged fermentations. International Journal of Engineering, Science and Technology 5: 19-24.

3. Huang $\mathrm{X}, \mathrm{Li} \mathrm{HM}$ (2009) Cloning and bioinformatics analysis of lovastatin biosynthesis regulatory gene lovE. Chin Med J (Engl) 122: 1800-1805.

4. Barrios-González J, Miranda RU (2010) Biotechnological production and applications of statins. Appl Microbiol Biotechnol 85: 869-883

5. Seenivasan A, Subhagar S, Aravindan R, Viruthagiri T (2008) Microbia production and biomedical applications of lovastatin. Indian J Pharm Sci 70: 701-709.

6. Barrios-González J, Baños JG, Covarrubias AA, Garay-Arroyo A (2008) Lovastatin biosynthetic genes of Aspergillus terreus are expressed differentially in solid-state and in liquid submerged fermentation. Appl Microbiol Biotechno 79: $179-186$

7. Bhargavi SD, Praveen VK, Savitha J (2014) Bioinformatics Comparative Analysis of Lovastatin Gene Cluster in Endophytic Fungi and a Soil Fungus, Aspergillus terreus. MOJ Proteomics and Bioinformatics 1: 1-4.

8. Praveen VK, Bhargavi SD, Savitha J (2014) Endophytic Fungi: A Poor Candidate for the Production of Lovastatin. British Microbiol Res J 4: 1511 1520.

9. Murashige $T$, Skoog $F$ (1962) A revised medium for rapid growth and bioassays with tobacco tissue cultures. Physiologia plantarum15: 473-497.
10. Kharwar RN, Mishra A, Gond SK, Stierle A, Stierle D (2011) Anticancer compounds derived from fungal endophytes: Their importance and future challenges. Nat Prod Rep 28: 1208-1228.

11. Mraz M, Malinova K, Mayer J, Pospisilova S (2009) MicroRNA isolation and stability in stored RNA samples. Biochem Biophys Res Commun 390: 1-4.

12. Wei Y, Lu L, Wenlong Z, Juan L, Jingyuan Y (2009) Comparison of RNA extraction methods applied to gene cloning of the taxol-producing fungi. African Journal of Microbiology Research 3: 632-636.

13. Kawasaki ES, Innis MA, Gelfand DH, Sninsky JJ, White (1990) TJ Amplification of RNA. In: PCR protocols: A guide to methods and applications Academic Press 21-27.

14. Strobel G, Daisy B (2003) Bioprospecting for microbial endophytes and their natural products. Microbiol Mol Biol Rev 67: 491-502.

15. Kharwar RN, Mishra A, Gond SK, Stierle A, Stierle D (2011) Anticancer compounds derived from fungal endophytes: their importance and future challenges. Nat Prod Rep 28: 1208-1228.

16. Laule O, Fürholz A, Chang HS, Zhu T, Wang X, et al. (2003) Crosstalk between cytosolic and plastidial pathways of isoprenoid biosynthesis in Arabidopsis thaliana. Proc Natl Acad Sci U S A 100: 6866-6871.

17. Kakimoto T (2003) Biosynthesis of cytokinins. J Plant Res 116: 233-239.

18. Joseph LG, Michael SB (1990) Regulation of the mevolonate pathway. Nature publishing group 425-430.

19. Thomas JC, McElwain EF, Bohnert HJ (1992) Convergent Induction of Osmotic Stress-Responses: Abscisic Acid, Cytokinin, and the Effects of $\mathrm{NaCl}$. Plant Physiol 100: 416-423.

20. Crowell DN, Salaz MS (1992) Inhibition of growth of cultured tobacco cells at low concentrations of lovastatin is reversed by cytokinin. Plant Physiol 100: 2090-2095.

21. Zhiguo J, Eric AC (2000) Lovastatin inhibits a-Farnesene synthesis without affecting ethylene production during fruit ripening in 'Golden Supreme' apples. J Amer soc hort sci 125: 105-110. 